\title{
On the Construction of Enterprise's Brand Strategy Ecosystem in the Perspective of Globalization
}

\author{
Zongwei HU, Jingyu CHEN \\ Department of Business University of Zhejiang Gongshang, Zhejiang Province, China \\ hzw310025@aliyun.com, 654074483@qq.com
}

\begin{abstract}
In this paper, the brand ecosystems at three levels and their brand synergies from the perspective of globalization was studied. Also, this paper roughly introduces the planning of brand strategy ecosystem and conducts an illuminative thought on the construction of brand strategy ecosystem.
\end{abstract}

Index Terms - Brand, Strategy, Ecosystem, Globalization.

\section{Introduction}

Today, economic globalization has become an unavoidable trend, and the business environment, which is becoming increasingly open and complicated, makes it rather difficult for an enterprise to continue to maintain its competitive edge. For an enterprise, in order to continue to maintain the competitiveness of its brand, it must pay enough attention to the relationship between enterprises and environment. The relationship among brand owners is no longer a simple relationship of competition or trading but a complex relationship of competition, corporation and learning from each other.

In recent year, some multinational brands began to enhance the their relationships with customers and suppliers, or even establish strategic alliances with their competitors, aiming to manufacture large and complex products and develop the market together as well as make use of each other's core resources. Today, for a brand, it is far from enough to take account of problems only from its own point of view, and it has to establish a business model with the function of sharing and coordination, thereby building a good business system with exceptional growth power and mobility. Just like the evolution of biological species, the new technologies and business models can affect the whole traditional business and have a great impact on the sustained and stable development of business. On the other hand, the development of business system can promote the generation of new technologies and business models as well as social progress. Therefore, business system can be described by referring to the biological ecosystem theory. In 1996, Moore put forward the business ecosystems theory, in which he defines business ecosystems as "the economic associations based on interaction of organizations and individuals". Such economic associations provide valuable products and services to consumers, and consumers are the members of the ecosystem. Also, in this ecosystem, there are some other organisms, such as suppliers, producers, competitors, and other risk bearers. A relationship of "co-evolution" exists among members in the ecosystem. The brand ecosystem theory begun in 1998 when David A Elk put forward the concept "brand community", and in the next year, Agnieszka Winkler put forward the concept "brand ecological environment", studied the related management problems, and pointed out that brand ecological environment is a complex, dynamic and ever-changing organic organization. Wang Xingyuan, a domestic scholar, established a relatively more comprehensive research framework of "brand ecology", whereby he studied the structure of brand ecosystem and principle of brand niche.

In the brand ecosystem, the development of corporate brand strategy is quite different from that of traditional strategy. When an enterprise wants to develop its brand strategy, it should not only take account of the brand ecosystem with mutual cooperative relations, but also take into account the development of brand ecosystem and the position of its own brand in this ecosystem. In this sense, competition is no longer regarded as existing among different brands but among different brand ecosystems as well as the members that want to occupy the leading position inside an ecosystem. In the brand ecosystem theory, competition is looked at from a new perspective, while globalization can be compared to a large market that can perfectly adapt to the collaborative ecological competition. For all the Chinese brands that are facing the challenges of globalization, how to construct and operate a good brand ecosystem has become a brand new topic.

\section{Structure of Brand Strategy Ecosystem}

As a complex adaptive system with loose and dynamic structure, the brand strategy ecosystem is made up of brand products/owners with the related enterprises, organizations or individuals by taking value transfer as the link and common evolution as the goal. It covers a wide range and includes all the factors that affect the survival and development of an enterprise, such as political environment, economic environment, global environment, generalized competitive environment, competitive environment of industries, information environment, and natural environment, etc. With its structure, logistics, commodity circulation, currency flow, and information flow being changed or partly changed artificially, the brand strategy ecosystem is actually a business system which takes core brand as the center and has been affected by enterprise's business activities. Therefore, the scope of brand biological strategy is much larger than that of strategic alliance, and it covers all the relationships of enterprises, including the relationships with suppliers, consumers, market intermediaries, competitors, the enterprises 
in other industries, government departments, universities, research institutions, and stakeholders, etc. Brand strategy ecosystem is an important part of the socio-economic ecological system, while the structure of brand strategy ecosystem can be described by extending the core ecosystem of an industry to the ecosystem of the industry and then to the macro ecosystem. The industrial brand ecosystem mainly refers to the brand ecosystem of a single brand, and it only covers customers of the brand, supply chain of the brand, and chain of resources. Macro-market brand ecosystem can be used to describe the brand ecosystem comprising many brand systems, including regional market brand ecosystem and industrial brand ecosystem.

It can be found that the development status of a brand depends on its individuality (genes) and internal ecological environment. Only to establish a proper brand ecosystem can brands achieve sustained and healthy development. In the brand ecological strategy, the core brand will strive to integrate the commercial elements that are originally unrelated into the new economic entity, thereby giving birth to new business, new rules of competition and cooperation, or even new industries. In this way, the connotation of brand competitiveness is extended, while this extension needs for a global vision. From this perspective, ecological competitiveness of brands can represent core brand's capacity in the integration and use of resources in global strategic ecosystem.

\section{Brand Relationship and Cooperative Mechanism in Brand Strategy Ecosystem}

\section{A. Ecological relationship of brand in brand strategy ecosystem}

Accurately identifying the ecological relationship between a brand and other individuals is a prerequisite for the effective implementation of brand management. By analyzing the business practice of enterprises, the author finds that the brand relationships include the following aspects in the ecological community of brands:

The most distinctive feature of this brand relationship is that technical factors are the core and starting point of all the business activities, in other words, technical factors are the key factors in conducting the operation and management of brand as well as allocation of resources. Such brand relationship maintained by technologies is established on the basis of the core technology, technology accumulation, trend of external technical evolution, technological innovation, and the introduction, absorption, digestion, and improvement of technologies of the core enterprise. For example, VLSI Research (Japan) can be regarded as a brand ecosystem established by enterprises, governments, universities and research institutes by taking technology as a link.

This brand relationship is based on the structure, nature and type of market, and its core is the market demand. Such relationship exists throughout the whole supply chain that is from suppliers to consumers, and it is the key part of the brand community. For instance, due to the market demand, UT
Starcom and China Telecom established a brand alliance in virtue of China's consumers in June, 2006, thereby greatly extended the life cycle of the handy-phone market.

Actually, the business activities of an enterprise are based on a wide range of knowledge-related factors, such as wisdom, information, strategies, and software, etc. Also, the factors of technology and market are also included in this relationship as a kind of knowledge. The trend and internal demand of ecological evolution are more intensive.

\section{B. Ecological coordination mechanism of brand in brand strategy ecosystem}

The vitality of a brand depends on its system status, resources and adaptation to the external market environment, in a words, it relies on the brand ecosystem. This represents the internal system comprising brands and brand owners, namely, the micro-brand ecosystem, which is the core and power source for individual brands to exist and develop. The brand supply ecological sub-system is made up of suppliers (S) and the environment, while brand market ecological subsystem is composed of middlemen (A), customers (C) and external environment (W). In the brand ecosystem, the brand owners, suppliers and customers make up of the core subsystem of brand strategy ecosystem. At the same time, the internal support system of brand is formed by corporate shareholders and employees; the external support system is composed of financial institutions and government sectors; while the environmental system for the brand consists of the public, competitors, media, and some other external factors. The relationship among members in the system is maintained by technology, market demand or knowledge. The members of brand ecosystem depend on each other for existence and achieve common development by relying on the brand equity. The cooperation in the brand ecosystem mainly includes niche coordination, industrial chain coordination, accumulative coordination, competitive coordination, and coordination among industries, etc. Niche coordination, which occurs among the different niches of a brand, is a kind of coordination of the brand itself; industrial chain coordination occurs in the ecological systems of brand supply and is the most common type of coordination; accumulative coordination appears in the regional or industrial brand clusters, and it is a way of expression of group effect; competitive coordination exists among competing brands, and it is the result of competing with each other, learning from each other, and pursuing each other; coordination among industries is, which is a innovative coordination, mainly exists among the seemingly irrelevant brands in different industries, while the key to activate synergistic effect rests with the affinity of complementarity and value between two synergistic brands.

In the ecosystem of an industry, different factors may have different impacts on the development of brands, while different brands not only competes with each other but also depends on each other for existence, resulting in the generation of industrial chain coordination, accumulative coordination and competitive coordination and the formation of various ecological conditions in an industry. From a more macro point 
of view, some different brands in different industries may constitute a more complicated macro brand ecosystem. The macro brand ecosystem is composed of many individual brands in a composite way. However, such composition can give birth to "lives", so the system is the space for brands to keep "alive" and is a complex macro system including brands, brand owners, marketing system, customer and the entire external environment.

It can be found that, while developing the ecological strategy of brand, the decision-makers should take into account three levels, namely, micro, meso and macro levels, and develop a "three-in-one" decision-making mode, in other words, the supporting power of evolution is from the macrostrategy mode, meso-strategy mode and micro- strategy mode. Also, with an interactive relationship existing among these three modes, they support and interact with each other, thereby becoming the three drivers of ecological evolution.

\section{Planning of Brand Strategy Ecosystem}

An important purpose of brand ecological strategy is to form the brand ecosystem and activate the synergy of brand, while the planning of brand strategy ecosystem is just the key to ensure the formation of ecological synergies of brand and lay a good foundation for the construction and development of the ecosystem, and is also the core of the brand ecology strategic management. The author believes that an integrated planning of brand strategy ecosystem should include the following aspects:

\section{A. Planning brand genes, choosing brand niche}

The substance of brand gene planning is to analyze the above-mentioned groups' awareness and expectation on the brand and create a brand values system that can be recognized by various social groups, thereby highlighting the brand personality of the brand owner. However, the competitive choice of multi-dimensional niche based on brand genes is the core part of brand strategy ecosystem planning. Especially, from the perspective of globalization, the choice of niche and protection for Chinese brands in the international competition should be paid the most attention to.

\section{B. Selecting members of the brand ecosystem, building a brand alliance}

The intensity of ecological effect of brand ecosystem depends on the quality of the ecological members. The brand managers should screen all the members in the brand ecosystem from the perspective of global brand strategy, and take full account of the ability and potential of their brand, thus ensuring the formation of resultant force of the brand alliance.

\section{Drawing the relations map of brand ecosystem}

Brand alliance is formed on the basis of the brand relations among different members, and only when the brand relations are harmonious can the brand effect be fully activated. Therefore, accurately identifying the relations between a brand and each member in the brand alliance as well as drawing the relations map are the prerequisites for the implementation of ecological management.

\section{Choosing brand ecological strategy}

As a brand new strategic mode, brand ecological strategy has become an important strategic choice for an enterprise to participate in the global market competition and obtain the advantages in the brand ecological competition. For all the Chinese brands, the most important thing now is to create a brand ecological structure and develop the special superiority of brand niche.

E. Building relationship management platform, developing management strategies, and promoting the ecological synergy of brand

The ultimate objective of the planning and management of brand strategy ecosystem is to maintain a harmonious ecological relationship. Building different relationship platforms and developing the corresponding management strategies is the focus of planning of brand strategy ecosystem and also the key to formation of brand ecosystem.

\section{Conclusions and Prospects}

The author draws the conclusion that the synergy of brand ecological strategies can not only create the competitive advantage of a brand effectively, but also achieve the common evolution of all the members in the system and the ecological evolution of the entire brand system.

\section{Acknowledgment}

We thanks the teachers of Zhejiang Gongshang University very much.

\section{References}

[1] T. Y. Choi, K. J. Dooley, and M. Rungtusanatham, "Supply networks and complex adaptive systems: control versus emergence," Journal of Operations Management, Vol. 19, no.3, pp. 351-366, 2001.

[2] J. Foster, "The analytical foundations of evolutionary economics: From biological analogy to economic self-organization," Structural Change and Economic Dynamics, Vol. 8, no.4, pp. 427-451, 1997.

[3] A. M. Goulielmos, "Complexity theory applied to management of shipping companies," Maritime Policy Management, Vol. 29, no.4, pp. 375-391, 2002.

[4] A. Hardagon, and R. I. Sutton, "Technology brokering and innovation in a product development firm," Administrative Science Quarterly, Vol. 42, no.4, pp. 716-749, 1997.

[5] J. Liedtka, "Ethics and the new economy," Business and Society Review, Vol. 107, no.1, pp. 1-19, 2002.

[6] J. F. Moore, "Predators and prey: the new ecology of competition," Harvard Business Review, Vol. 71, no.3, pp. 75-83, 1993.

[7] P. H. Phan, D. S. Siegel, and M. Wright, "Science parks and incubators: observations, synthesis and future research," Journal of Business venturing, Vol. 20, no.2, pp.165-183, 2005.

[8] T. Veblen, "Why is economics not an evolutionary science?," The Quarterly Journal of Economics, Vol. 12, no.4, pp. 373-397, 1898.

[9] U. Witt, "Self-organization and economics - what is new?," Structural Change and Economic Development, Vol. 8, no.4, pp. 489-507, 1997. 